\title{
Hydrogen sulphide synthesis (version 2019.4) in the IUPHAR/BPS Guide to Pharmacology Database
}

Timothy R. Billiar ${ }^{1}$, Giuseppe Cirino ${ }^{2}$, David Fulton ${ }^{3}$, Roberto Motterlini ${ }^{4}$, Andreas Papapetropoulos ${ }^{5}$ and Csaba Szabo 6

1. University of Pittsburgh, USA

2. University of Naples-Federico II, Italy

3. Georgia Regents University, USA

4. University of Paris Est Creteil, France

5. University of Athens, Greece

6. University of Texas, USA

\begin{abstract}
Hydrogen sulfide is a gasotransmitter, with similarities to nitric oxide and carbon monoxide. Although the enzymes indicated below have multiple enzymatic activities, the focus here is the generation of hydrogen sulphide $\left(\mathrm{H}_{2} \mathrm{~S}\right)$ and the enzymatic characteristics are described accordingly. Cystathionine $\beta$-synthase (CBS) and cystathionine $y$-lyase (CSE) are pyridoxal phosphate (PLP)-dependent enzymes. 3-mercaptopyruvate sulfurtransferase (3-MPST) functions to generate $\mathrm{H}_{2} \mathrm{~S}$; only CAT is PLP-dependent, while 3-MPST is not. Thus, this third pathway is sometimes referred to as PLP-independent. CBS and CSE are predominantly cytosolic enzymes, while 3-MPST is found both in the cytosol and the mitochondria. For an authoritative review on the pharmacological modulation of $\mathrm{H}_{2} \mathrm{~S}$ levels, see Szabo and Papapetropoulos, 2017 [4].
\end{abstract}

\section{Contents}

This is a citation summary for Hydrogen sulphide synthesis in the Guide to Pharmacology database (GtoPdb). It exists purely as an adjunct to the database to facilitate the recognition of citations to and from the database by citation analyzers. Readers will almost certainly want to visit the relevant sections of the database which are given here under database links.

GtoPdb is an expert-driven guide to pharmacological targets and the substances that act on them. GtoPdb is a reference work which is most usefully represented as an on-line database. As in any publication this work should be appropriately cited, and the papers it cites should also be recognized. This document provides a citation for the relevant parts of the database, and also provides a reference list for the research cited by those parts.

Please note that the database version for the citations given in GtoPdb are to the most recent preceding version in which the family or its subfamilies and targets were substantially changed. The links below are to the current version. If you need to consult the cited version, rather than the most recent version, please contact the GtoPdb curators.

\section{Database links}


Hydrogen sulphide synthesis

http://www.guidetopharmacology.org/GRAC/FamilyDisplayForward?familyld=279

Enzymes

CBS(Cystathionine $\beta$-synthase)

http://www.guidetopharmacology.org/GRAC/ObjectDisplayForward?objectld=1443

CSE(Cystathionine $\gamma$-lyase)

http://www.guidetopharmacology.org/GRAC/ObjectDisplayForward?objectld=1444

CAT(L-Cysteine:2-oxoglutarate aminotransferase)

http://www.guidetopharmacology.org/GRAC/ObjectDisplayForward?objectld=1445

MPST(3-Mercaptopyruvate sulfurtransferase)

http://www.guidetopharmacology.org/GRAC/ObjectDisplayForward?objectld=1446

\section{References}

1. Asimakopoulou A, Panopoulos P, Chasapis CT, Coletta C, Zhou Z, Cirino G, Giannis A, Szabo C, Spyroulias GA and Papapetropoulos A. (2013) Selectivity of commonly used pharmacological inhibitors for cystathionine $\beta$ synthase (CBS) and cystathionine y lyase (CSE). Br. J. Pharmacol. 169: 922-32 [PMID:23488457]

2. Chen X, Jhee KH and Kruger WD. (2004) Production of the neuromodulator H2S by cystathionine betasynthase via the condensation of cysteine and homocysteine. J. Biol. Chem. 279: 52082-6 [PMID:15520012]

3. Nagahara N, Okazaki T and Nishino T. (1995) Cytosolic mercaptopyruvate sulfurtransferase is evolutionarily related to mitochondrial rhodanese. Striking similarity in active site amino acid sequence and the increase in the mercaptopyruvate sulfurtransferase activity of rhodanese by site-directed mutagenesis. J. Biol. Chem. 270: 16230-5 [PMID:7608189]

4. Szabo $C$ and Papapetropoulos A. (2017) International Union of Basic and Clinical Pharmacology. CII: Pharmacological Modulation of H2S Levels: H2S Donors and H2S Biosynthesis Inhibitors. Pharmacol. Rev. 69: 497-564 [PMID:28978633]

5. Tuttle JB, Anderson M, Bechle BM, Campbell BM, Chang C, Dounay AB, Evrard E, Fonseca KR, Gan X and Ghosh S et al.. (2013) Structure-Based Design of Irreversible Human KAT II Inhibitors: Discovery of New Potency-Enhancing Interactions. ACS Med Chem Lett. 2: 37-40 